\title{
HUBUNGAN ANTARA INVESTASI DAN KUALITAS ANAK USIA SEKOLAH PADA KELUARGA PETANI
}

\author{
Tri Sari Asih Rahmiati ${ }^{1}$, Herien Puspitawati ${ }^{1 *}$ \\ ${ }^{1}$ Departemen IImu Keluarga dan Konsumen, Fakultas Ekologi Manusia, Institut Pertanian Bogor, \\ Bogor 16680, Indonesia \\ ${ }^{*}$ E-mail: herein_puspitawati@email.com
}

\begin{abstract}
Abstrak
Sumber daya manusia yang berkualitas dapat dihasilkan melalui investasi anak yang dilakukan oleh orang tua. Penelitian ini bertujuan untuk menganalisis hubungan antara investasi dan kualitas anak usia sekolah pada keluarga petani di Kabupaten Cirebon, Provinsi Jawa Barat. Contoh dalam penelitian ini adalah keluarga petani yang memiliki anak usia sekolah (11-12 tahun) di Desa Buyut yang dipilih secara acak. Penelitian ini melibatkan 30 keluarga petani. Pengambilan data dilakukan melalui wawancara menggunakan kuesioner dan wawancara mendalam. Data dianalisis menggunakan uji korelasi. Investasi anak terdiri atas investasi materi (pengeluaran keluarga untuk anak) dan nonmateri (alokasi waktu, komunikasi orang tua-anak, dan pola asuh). Kualitas anak terdiri atas kualitas fisik, kognitif, psikososial, dan perilaku anak. Hasil penelitian menunjukkan bahwa investasi dan kualitas anak pada keluarga petani tergolong dalam kategori sedang. Investasi anak semakin baik dengan bertambahnya usia anak dan pendidikan orang tua. Investasi keluarga khususnya investasi nonmateri berhubungan signifikan dengan kualitas anak. Kualitas anak semakin baik dengan semakin besarnya investasi nonmateri yang dilakukan keluarga.
\end{abstract}

Kata kunci: alokasi waktu ibu, investasi anak, perilaku anak, pola asuh, anak usia sekolah

\section{Relationship Between Investment and Quality of School-Age Children at Farmer Families}

\begin{abstract}
Abtract
Quality of human resources can be generated by child investment that conducted by parents. The study aimed to analyze correlation between investment and quality of school-aged children of farmer family in Cirebon District, West Java Province. Samples were farmer families who had children of school-age (11-12 years) in Buyut village that were selected by simple random sampling. This research involved 30 farmer families. Data was collected by interview with questionnaires and in-depth interview. Data was analyzed by correlation test. Child investment consist of material investment (family expenditure for child) and nonmaterial investment (time allocation, parent-child communication, and parenting pattern). Child quality consist of physical quality, cognitive quality, psicosocial quality, and child behavior. The results showed that child investment and child quality of farmer families were in the moderate category. Child investment will be better with increasing child's age and parental education. Family investment especially nonmaterial investments correlated significantly with child quality. Child quality will be better with increasing nonmaterial investment who were done by family.
\end{abstract}

Keywords: child behavior, child investment, maternal time allocation, parenting, school-aged children

\section{PENDAHULUAN}

Peran genarasi muda dalam pembangunan nasional sebagai agen perubahan di berbagai bidang pembangunan merupakan peran strategis. Generasi muda yang memiliki sifat dinamis, berorientasi masa depan, terbuka, kreatif, dan empati akan dapat mengubah keadaan sejarah suatu bangsa menjadi baik (Tangdilintin, 2008). Apabila kelima potensi ini diasah dan diberikan fasilitas yang baik oleh pemerintah maka akan menghasilkan sumber daya manusia yang berkuali- tas. Indikator sumber daya manusia berkualitas dapat dilihat dari Human Development Index (HDI) atau Indeks Pembangunan Manusia (IPM). Tahun 2013, IPM Indonesia menempati urutan 108 dari 187 negara.

Keberadaan institusi keluarga mempunyai peran penting dalam membentuk generasi muda yang berkualitas karena keluarga adalah agen utama dalam proses sosialisasi. Saat ini, keberfungsian keluarga mulai menurun karena terjadi pengaburan peran dan fungsi keluarga. $\mathrm{Hal}$ ini disebabkan kondisi masyarakat 

Indonesia yang sebagian besar mengalami kesulitan untuk memenuhi kebutuhan hidupnya. Kesulitan ekonomi keluarga yang berlangsung lama dapat menimbulkan masalah kemiskinan.

Kemiskinan identik dengan keluarga yang tinggal di perdesaan terutama keluarga petani yang masih menerapkan pola pertanian subsisten. Sejalan dengan Todaro dan Smith (2006), dua pertiga penduduk miskin di negaranegara berkembang terutama yang bekerja sebagai petani atau buruh tani masih menggantungkan hidupnya pada pola pertanian yang subsisten. Penerapan pola pertanian subsisten banyak menimbulkan sisi negatif. Salah satunya adalah rendahnya produksi pertanian yang mengakibatkan rendahnya pendapatan yang diterima.

Pendapatan yang rendah mendorong munculnya masalah ekonomi keluarga. Masalah ini menyebabkan keluarga sulit untuk berinvestasi. Hasil penelitian sebelumnya menunjukkan bahwa keluarga yang bekerja sebagai buruh tani memiliki perilaku investasi pendidikan dan kesehatan dalam kategori sedang, yaitu 81,8 persen dan 51,5 persen (Rosidah, Hartoyo, \& Muflikhati, 2012). Selain itu, Rochaeni dan Lokollo (2005) menyatakan bahwa persentase pengeluaran rumah tangga petani lebih besar pada pengeluaran pangan $(26,2 \%)$ dibandingkan untuk investasi pendidikan (12,2\%). Hal tersebut menunjukkan bahwa keluarga yang tinggal di perdesaan dan bekerja sebagai petani atau buruh tani jarang mengutamakan biaya investasi untuk anak dibandingkan memenuhi kebutuhan pangan. Praktik inilah yang mengakibatkan rendahnya kualitas anak yang tinggal di perdesaan.

Proses hubungan interaksi keluarga dan lingkungan saling memengaruhi. Hal ini dapat digambarkan melalui model ekologi keluarga yang dikembangkan oleh Bronfenbrenner (1979). Seorang anak akan selalu berkembang dalam konteks komunikasi antar anggota keluarga sehingga membentuk perkembangan anak yang merupakan hasil dari beberapa faktor yang memengaruhi interaksi lingkungan keluarga. Terkait dengan model ekologi keluarga Bronfenbrenner (1979), lingkungan keluarga memengaruhi pola hidup keluarga termasuk kebutuhan keluarga. Keluarga yang mempunyai status ekonomi baik dan latar belakang pendidikan orang tua yang baik pula tentunya akan merencanakan investasi sumber daya manusia yang lebih baik. Sebaliknya, pendapatan dan latar belakang pendidikan orang tua yang rendah cenderung jarang merencanakan investasi untuk anak sehingga kualitas anak juga akan menjadi rendah.

Secara umum penelitian ini bertujuan untuk menganalisis investasi dan kualitas anak usia sekolah pada keluarga petani di Kabupaten Cirebon. Secara khusus, penelitian ini bertujuan untuk: (1) menganalisis investasi anak pada keluarga petani, (2) menganalisis kualitas anak berdasarkan dimensi fisik, dimensi akademik, dimensi psikososial, dan dimensi perilaku anak, (3) menganalisis hubungan antara karakteristik keluarga, karakteristik anak, dan karakteristik lingkungan petani dengan investasi dan kualitas anak, dan (4) menganalisis hubungan antara investasi anak dengan kualitas anak.

\section{METODE}

Penelitian ini menggunakan desain cross sectional. Lokasi penelitian adalah Desa Buyut, Kecamatan Gunung Jati, Kabupaten Cirebon, Provinsi Jawa Barat. Pemilihan lokasi penelitian dilakukan secara purposive karena Desa Buyut identik dengan komunitas petani padi sawah terluas di Kabupaten Cirebon. Waktu pengambilan data dilakukan pada bulan April 2012.

Populasi dalam penelitian adalah keluarga petani di Desa Buyut, Kecamatan Gunung Jati, Kabupaten Cirebon. Kerangka contoh dari penelitian ini adalah keluarga petani yang memiliki anak usia sekolah (11-12 tahun) yang diambil secara acak dari populasi penelitian. Adapun responden dari penelitian ini adalah ibu dan anak dari kerangka contoh terpilih. Jumlah keluarga petani yang menjadi contoh dalam penelitian ini adalah 30 keluarga.

Data primer dalam penelitian ini meliputi karakteristik keluarga (besar keluarga, usia orang tua, jumlah anak yang sekolah, pendidikan orang tua, pekerjaan orang tua, dan pendapatan keluarga), karakteristik anak (jenis kelamin, usia, dan tingkatan kelas), karakteristik lingkungan petani (nilai-nilai masyarakat, sarana dan prasarana serta dukungan masyarakat), investasi anak secara materi (alokasi pengeluaran umum keluarga, alokasi pengeluaran khusus anak, untuk pendidikan dan kesehatan), investasi anak secara nonmateri (frekuensi komunikasi orang tua dan anak, pola asuh, dan alokasi waktu ibu dan anak), dan kualitas anak (dimensi fisik, dimensi akademik, dimensi psikososial, dan dimensi perilaku anak). 

Usia orang tua dikategorikan berdasarkan Hurlock (1980), yaitu dewasa awal (18-40 tahun), dewasa madya (41-60 tahun), dan dewasa akhir (61 tahun keatas). Pendidikan orang tua dikategorikan ke dalam empat kategori, yaitu tidak sekolah, SD/sederajattamat, SMP/sederajat-tamat, dan SMA/ sederajat-tamat. Pekerjaan orang tua dibagi dalam dua macam, yaitu pekerjaan utama dan tambahan. Besar keluarga dikategorikan menurut BKKBN (1998) menjadi tiga, yaitu keluarga keci (jumlah anggota keluarga $\leq 4$ orang), keluarga menengah (jumlah anggota keluarga 5-7 orang), dan keluarga besar (jumlah anggota keluarga lebih dari 7 orang). Pendapatan keluarga menggunakan Batas Garis Kemiskinan perdesaan Jawa Barat. Alokasi pengeluaran yang menjadi ukuran investasi anak secara materi menggunakan rasio ( $\mathrm{Rp} /$ bulan).

Alokasi waktu menggunakan metode recall 24 jam. Sementra itu, untuk investasi anak secara nonmateri pada dimensi frekuensi komunikasi diukur dengan 11 pertanyaan diukur dengan menggunakan kuesioner dengan nilai Cronbach's alpha 0,862 dan merupakan adaptasi dan modifikasi dari Puspitawati (2012). Fasilitas pendidikan dan kesehatan terdiri atas 20 pertanyaan diukur dengan menggunakan kuesioner dengan nilai Cronbach's alpha 0,767 dan merupakan adaptasi dan modifikasi dari Puspitawati (2012).

Investasi anak materi yang terdiri atas alokasi pengeluaran keluarga dan alokasi pengeluaran keluarga khusus anak memiliki jumlah pertanyaan sebanyak 13 pertanyaan. Investasi nonmateri yang terdiri atas frekuensi komunikasi orang tua dan anak memiliki jumlah pertanyaan sebanyak 11 dan nilai Cronbach's alpha adalah 0,862. Pola asuh memiliki jumlah pertanyaan sebanyak 40 dan nilai Cronbach's alpha adalah 0,873 kecuali kewajiban anak di keluarga berupa pertanyaan terbuka. Alokasi waktu ibu dan anak diukur dengan menggunakan metode recall 24 jam kemudian diambil waktu kegiatan bersama antara ibu dan anak dalam menit/hari. Pola asuh terdiri atas 10 pertanyaan pola asuh belajar, 10 pertanyaan pola asuh hidup sehat, 10 pertanyaan pola asuh sosial emosi, 10 pertanyaan perlindungan anak, dan 5 pertanyaan terbuka kewajiban anak di keluarga. Pola asuh belajar, pola asuh hidup sehat, pola asuh sosial emosi, dan perlindungan anak diukur dengan menggunakan kuesioner dengan nilai Cronbach's alpha 0,873 . Pola asuh akademik merupakan adaptasi dan modifikasi dari Puspitawati (2010). Pola asuh hidup sehat dan sosial emosi merupakan adaptasi dan modifikasi dari Hastuti (2009).

Setelah data diperoleh, frekuensi komunikasi dan pola asuh ditransformasi ke dalam indeks sehingga didapat indeks nonmateri. Fasilitas pendidikan dan kesehatan ditransformasi ke dalam indeks sehingga di dapat indeks materi. Indeks materi dan nonmateri digabung menjadi Indeks Investasi Anak (IIA) kemudian dikategorikan dalam kategori rendah $(0,0-33,3)$, sedang $(33,4-66,7)$, dan tinggi $(66,7-100,0)$.

Kualitas anak terdiri atas 6 pertanyaan dimensi fisik, 5 pertanyaan dimensi kognitif, 40 pertanyaan dimensi psikososial, dan 40 pertanyaan dimensi perilaku anak. Dimensi psikososial dan perilaku anak diukur dengan menggunakan kuesioner dengan nilai Cronbach's alpha 0,702 dan 0,554. Dimensi psikososial dan perilaku anak merupakan adaptasi dan modifikasi dari Puspitawati (2012). Masing-masing dimensi kualitas anak ditransformasikan ke dalam indeks sehingga di dapat Indeks Kualitas Anak (IKA). IKA dikategorikan ke dalam kategori rendah $(0,0$ $33,3)$, sedang $(33,4-66,7)$, dan tinggi $(66,7-$ $100,0)$.

Data diperoleh dengan wawancara secara terstruktur menggunakan kuesioner. Analisis data dilakukan secara deskriptif dan inferensial. Dalam penelitian ini, analisis data yang digunakan adalah analisis deskriptif untuk mengukur rata-rata, standar deviasi, nilai minimum, dan nilai maksimum. Uji korelasi Pearson untuk menganalisis hubungan antara karakteristik keluarga, karakteristik anak, dan karakteristik lingkungan petani dengan investasi dan kualitas anak, antara karakteristik keluarga, karkteristik anak, dan karakteristik lingkungan petani dengan kualitas anak serta antara investasi anak dengan kualitas anak.

\section{HASIL}

\section{Karakteristik Keluarga dan Anak}

Karakteristik keluarga terdiri atas besar keluarga, usia orang tua, jumlah anak yang sekolah, pendidikan orang tua, pekerjaan orang tua, dan pendapatan keluarga. Karakteristik anak terdiri atas jenis kelamin, usia, dan tingkatan kelas. Nilai minimum, maksimum, rata-rata, dan standar deviasi untuk karakteristik keluarga dan karakteristik anak keluarga petani yang terlibat dalam penelitian ini disajikan pada Tabel 1. 

Tabel 1 Nilai minimum, maksimum, rata-rata, dan standar deviasi dari karakteristik keluarga dan anak

\begin{tabular}{lrr}
\hline $\begin{array}{l}\text { Karakteristik keluarga } \\
\text { dan anak }\end{array}$ & $\begin{array}{r}\text { Minimum- } \\
\text { Maksimum }\end{array}$ & $\begin{array}{c}\text { Rata-rata } \\
\text { Standar } \\
\text { deviasi }\end{array}$ \\
\hline Usia ayah (tahun) & $34-67$ & $44,9 \pm 8,7$ \\
Usia ibu (tahun) & $30-65$ & $39,9 \pm 7,3$ \\
Besar keluarga (orang) & $3-9$ & $5,3 \pm 1,6$ \\
Pendapatan keluarga & $41.667-$ & $301.141 \pm$ \\
(Rp/kaipta/bulan) & 1.783 .333 & 375.298 \\
Usia anak (tahun) & $11-14$ & $12,3 \pm 0,8$ \\
\hline
\end{tabular}

Separuh ayah (50,0\%) berada pada kategori dewasa madya dengan rata-rata usia ayah adalah 44,9 tahun dan dua pertiga ibu $(66,7 \%)$ berada pada kategori dewasa awal dengan rata-rata usia ibu adalah 39,9 tahun. Hal ini menunjukkan bahwa rata-rata-rata usia orang tiga berada pada kategori dewasa awal dan dewasa madya. Lebih dari tiga perempat ayah $(76,7 \%)$ dan sebagian besar ibu $(93,3 \%)$ hanya menempuh pendidikan sampai dengan SD/sederajat. Rata-rata besar keluarga responden berada pada kategori keluarga sedang (5-7 orang). Sebagian besar ayah $(90,0 \%)$ memiliki pekerjaan utama sebagai buruh tani dan sebagian besar ibu $(80,0 \%)$ tidak memiliki pekerjaan utama hanya sebagai IRT (Ibu Rumah Tangga). Separuh ayah $(50,0 \%)$ dan lebih separuh ibu $(60,0 \%)$ tidak memiliki pekerjaan tambahan.

Pendapatan keluarga responden dibandingkan dengan garis kemiskinan perdesaan Provinsi Jawa Barat yaitu sebesar Rp204.199/ kapita/bulan (BPS, 2011). Hasil perbandingan antara pendapatan keluarga dengan garis kemiskinan menunjukkan bahwa 60 persen keluarga responden tergolong dalam kategori miskin yaitu memiliki pendapatan keluarga per kapita kurang dari garis kemiskinan. Selanjutnya, 26,7 persen keluarga responden tergolong hampir miskin yang memiliki pendapatan keluarga per kapita mendekati dengan garis kemiskinan. Hasil perbandingan juga menemukan bahwa sebesar 13,3 persen keluarga responden tergolong dalam keluarga tidak miskin (menengah ke atas).

Rata-rata usia anak laki-laki responden maupun anak perempuan responden adalah 12,3 tahun. Hal ini menunjukkan bahwa usia anak dalam penelitian ini memasuki tahap masa kanak-kanak akhir menuju tahap awal remaja. Pada masa kanak-kanak akhir terdapat perubahan penting yaitu perubahan perkembangan emosi (Wintre \& Vallance, 1994 diacu dalam Santrock, 2007). Hasil penelitian lainnya menunjukkan bahwa lebih separuh anak lakilaki responden $(60,0 \%)$ dan anak perempuan responden $(53,3 \%)$ berada pada kelas 5 dan kelas 6. Nilai minimum, maksimum, rata-rata, dan standar deviasi karakteristik keluarga dan anak dapat dilihat pada Tabel 1.

\section{Karakteristik Lingkungan Petani}

Nilai budaya. Nilai budaya Pantai Utara (Pantura) yang merupakan nilai-nilai umum dianut oleh masyarakat di lokasi penelitian menunjukkan bahwa tidak ada batasan atau larangan dalam keluarga $(30,0 \%)$, anak-anak jangan terlalu banyak diberi kebebasan bermain $(3,3 \%)$, seorang anak laki-laki di dalam keluarga harus dididik keras agar kuat dalam menjalani kehidupan masa depannya (3,3\%), seorang anak perempuan di dalam keluarga harus memiliki tata krama yang baik dan lembut $(3,3 \%)$, anak-anak harus menuruti perkataan orang tua $(10,0 \%)$, dan orang tua selalu memberikan nasehat, menanamkan nilai sopan santun, dan berbuat baik $(33,3 \%)$.

Nilai sosial. Nilai sosial yang ditemukan sebagai nilai-nilai budaya yang diyakini masyarakat pada lokasi penelitian menunjukkan bahwa seorang anak dapat memahami dan mengerti keadaan orang tuanya serta jangan ikut terpengaruh perilaku teman yang buruk $(3,3 \%)$, seorang anak dapat berteman dengan baik $(16,7 \%)$, seorang anak diberikan batasan waktu dalam bermain dan anak perempuan memiliki batasan bergaul dengan anak laki-laki $(23,3 \%)$, seorang anak jangan suka memilih teman dan harus saling membantu $(23,3 \%)$, dan orang tua tidak memberikan batasan untuk anak laki-laki maupun anak perempuan $(26,7 \%)$.

Nilai ekonomi. Nilai ekonomi pada lokasi penelitian menunjukkan bahwa orang tua memberikan kebebasan kepada anaknya untuk bekerja atau tidak $(3,3 \%)$, seorang anak harus membantu orang tua agar beban hidup keluarga sedikit berkurang (3,3\%), seorang anak laki-laki dalam keluarga harus kerja untuk membantu orang tua $(3,3 \%)$, dan seorang anak boleh bekerja jika sudah dewasa $(90,0 \%)$.

Nilai pendidikan. Nilai pendidikan pada keluarga petani di lokasi penelitian menunjukkan bahwa orang tua menginginkan anaknya dapat bersekolah dengan baik jangan sampai seperti orang tuanya $(3,3 \%)$, pendidikan tidak penting karena banyak menghabiskan biaya $(3,3 \%)$, pendidikan sebagai bekal ilmu masa depan anak $(6,6 \%)$, orang tua ingin menyekolahkan anaknya sampai tinggi jika ada biaya $(43,3 \%)$, dan pendidikan sangat penting untuk kebaikan masa depan anak $(46,7 \%)$. 


\section{Investasi Anak}

Keberhasilan anak dalam keluarga tergantung dari investasi yang dilakukan oleh orang tua. Investasi orang tua merupakan tindakan yang dilakukan oleh orang tua kepada anaknya agar dapat meningkatkan kesempatan serta bertahan hidup lebih layak bagi anak dan generasi selanjutnya (Trivers, 1972 diacu dalam Routledge, 2004). Investasi anak dapat berbentuk materi dan nonmateri. Investasi materi terdiri atas alokasi pengeluaran umum keluarga, alokasi pengeluaran khusus anak, fasilitas pendidikan, dan fasilitas kesehatan, sedangkan investasi nonmateri meliputi alokasi waktu, frekuensi komunikasi orang tua-anak, dan pola asuh. Hasil penelitian menunjukkan bahwa dua pertiga keluarga petani $(66,7 \%)$ memiliki investasi anak pada kategori sedang dengan rata-rata indeks 61,0 (Tabel 2). Selaras dengan Lee (2007) yang menyatakan bahwa keluarga yang memiliki dua orang anak maka nilai investasi per anak hanya 67,7 persen.

\section{Kualitas Anak}

Kualitas anak merupakan cerminan kualitas bangsa dan peradaban dunia. Kualitas anak atau derajat kehandalan dapat dilihat dari pertumbuhan dan perkembangan anak (Sunarti, 2004). Hasil penelitian menunjukkan bahwa dua pertiga anak (66,7\%) memiliki kualitas anak pada kategori sedang dengan rata-rata indeks sebesar 55,4. Hal ini membuktikan bahwa pencapaian dimensi fisik, dimensi akademik, dimensi psikososial, dan dimensi perilaku anak relatif kurang baik. Hasil ini didukung dengan Soetjiningsih (1995), pada keluarga yang berpenghasilan rendah upaya untuk meningkatkan kualitas hidup anak masih belum menjadi prioritas utama dalam kehidupan keluarga. Adapun persentase kategori kualitas anak tinggi sebesar 33,3 persen dan tidak ada anak yang memiliki kualitas anak pada kategori rendah dengan rata-rata 55,4 dan indeks minimum 40,4 serta indeks maksimum 69,2. Sebaran keluarga responden berdasarkan indeks kuaitas anak dapat dilihat pada Tabel 3.

Tabel 2 Sebaran keluarga responden berdasarkan kategori indeks investasi anak

\begin{tabular}{lrr}
\hline \multicolumn{1}{c}{ Kategori } & Jumlah & Persentase \\
\hline Rendah $(0,0-33,3)$ & 0 & 0,0 \\
Sedang $(33,4-$ & 20 & 66,7 \\
$66,7)$ & & \\
Tinggi $(66,7-100)$ & 10 & 33,3 \\
\hline Total & 30 & 100,0 \\
\hline
\end{tabular}

Tabel 3 Sebaran keluarga responden berdasarkan kategori kualitas anak

\begin{tabular}{lrr}
\hline Kategori & Jumlah & Persentase \\
\hline Rendah $(\leq 33,3 \%)$ & 0 & 0,0 \\
Sedang $(33,4 \%-66,7 \%)$ & 20 & 66,7 \\
Tinggi $(>66,7 \%)$ & 10 & 33,3 \\
\hline Total & 30 & 100,0 \\
\hline
\end{tabular}

Hubungan Karakteristik Keluarga, Karakteristik Anak, dan Karakteristik Lingkungan Petani dengan Investasi Anak

Hasil uji korelasi Pearson menunjukkan bahwa terdapat hubungan positif signifikan antara usia anak dengan indeks investasi anak $(r=0,408, p<0,05)$ dan indeks materi $(r=0,430$, $p<0,05)$. Hal ini menunjukkan bahwa semakin bertambah usia anak maka semakin tinggi investasi anak dan investasi materi yang diberikan oleh orang tua. Dalam hasil penelitian, pengeluaran pangan dan nonpangan khusus anak sebesar 80,1 persen dan 19,9 persen. Hal ini sesuai dengan pernyataan Lino (2004) dalam penelitiannya bahwa keluarga yang berpenghasilan rendah memiliki estimasi pengeluaran untuk kebutuhan anak per tahun sebesar 28,0 persen atau $\$ 6,820-\$ 7,840$.

Hasil uji korelasi Pearson menunjukkan bahwa terdapat hubungan positif signifikan $(r=0,382, \quad p<0,05)$ antara pendidikan ayah dengan indeks investasi anak. Artinya, semakin tinggi pendidikan ayah maka semakin baik investasi anak. Selain itu, terdapat hubungan positif signifikan $(r=0,407, p<0,05)$ antara pendidikan ibu dengan indeks investasi anak. Hal ini menunjukkan bahwa semakin tinggi pendidikan ibu maka semakin baik investasi anak. Sejalan dengan penelitian Lee (2007), orang tua yang berpendidikan tinggi akan berinvestasi lebih banyak untuk pendidikan anak. Hal ini menunjukkan bahwa semakin tinggi tingkat pendidikan orang tua maka semakin baik investasi pendidikan anak.

Hasil uji korelasi Pearson menunjukkan bahwa terdapat hubungan positif signifikan $(r=0,367, p<0,05)$ antara pendapatan keluarga (Rp/kapita/bulan) dengan investasi nonmateri. Semakin tinggi pendapatan keluarga per kapita maka semakin baik investasi nonmateri untuk anak. Sejalan dengan Gunarsa dan Gunarsa (1995) bahwa orang tua yang berpendapatan tinggi memiliki waktu lebih banyak untuk memperhatikan perkembangan anak. Hubungan antara karakteristik keluarga, karaktyeristik anak, dan karakteristik lingkungan dengan investasi anak disajikan pada Tabel 4. 
Tabel 4 Koefisien korelasi untuk analisis hubungan karakteristik keluarga, karakteristik anak, dan karakteristik lingkungan petani dengan investasi anak

\begin{tabular}{|c|c|c|c|}
\hline Variabel & $\begin{array}{l}\text { Indeks } \\
\text { Materi }\end{array}$ & $\begin{array}{l}\text { Indeks } \\
\text { Nonmateri }\end{array}$ & $\begin{array}{l}\text { Indeks } \\
\text { Investasi } \\
\text { Anak } \\
\text { (IIA) }\end{array}$ \\
\hline Usia anak & $0,430^{*}$ & 0,267 & $0,408^{*}$ \\
\hline $\begin{array}{l}\text { Tingkatan kelas } \\
\text { anak }\end{array}$ & 0,177 & $-0,106$ & 0,032 \\
\hline $\begin{array}{l}\text { Jumlah anak } \\
\text { yang masih } \\
\text { sekolah }\end{array}$ & $-0,116$ & $-0,109$ & $-0,132$ \\
\hline Besar keluarga & 0,307 & $-0,273$ & $-0,001$ \\
\hline Usia ayah & 0,127 & $-0,143$ & $-0,019$ \\
\hline Usia ibu & $-0,076$ & $-0,033$ & $-0,062$ \\
\hline $\begin{array}{l}\text { Pendidikan } \\
\text { ayah }\end{array}$ & 0,348 & 0,298 & $0,382^{*}$ \\
\hline Pendidikan ibu & 0,333 & 0,353 & $0,407^{*}$ \\
\hline $\begin{array}{l}\text { Pendapatan } \\
\text { keluarga per } \\
\text { kapita }\end{array}$ & $-0,051$ & $0,367^{*}$ & 0,202 \\
\hline $\begin{array}{l}\text { Akses sarana } \\
\text { pendidikan }\end{array}$ & 0,170 & 0,033 & 0,115 \\
\hline $\begin{array}{l}\text { Akses sarana } \\
\text { kesehatan }\end{array}$ & $-0,060$ & 0,260 & 0,129 \\
\hline
\end{tabular}

Hubungan Karakteristik Keluarga, Karakteristik Anak, dan Karakteristik Lingkungan Petani dengan Kualitas Anak

Hasil uji korelasi Pearson menunjukkan bahwa terdapat hubungan positif signifikan $(r=0,365, p<0,05)$ antara usia anak dengan dimensi akademik (Tabel 5). Hasil ini menunjukkan bahwa semakin bertambah usia anak maka semakin baik akademik anak. Hasil ini sejalan dengan teori Piaget bahwa anak usia 11-12 tahun termasuk dalam tahap operasional konkrit. Artinya, pemikiran anak mulai berkembang lebih logis, fleksibel, dan terorganisir dibandingkan anak usia dini. Hal ini menunjukkan bahwa kematangan berpikir anak akan berkembang sesuai pertambahan usia anak dan bersifat dinamis.

Hasil uji korelasi Pearson menunjukkan bahwa terdapat hubungan positif sangat signifikan $(r=0,492, \quad p<0,01)$ antara besar keluarga dengan dimensi psikososial anak (Tabel 5). Artinya, semakin bertambah ukuran besar keluarga maka semakin baik psikososial anak. Hal ini didukung dengan Hastuti, Fiernanti, dan Guhardja (2011) yang menyatakan bahwa perkembangan sosial emosi anak tidak lepas dari peran pengasuhan psikososial yang dilakukan oleh keluarga. Oleh karena itu, salah satu faktor yang berhubungan dengan perkembangan sosial emosi anak adalah lingkungan keluarga.

Selanjutnya, terdapat hubungan positif signifikan $(r=0,379, r=0,380 p<0,05)$ antara usia ibu dengan indeks kualitas anak dan dimensi akademik (Tabel 5). Hal ini menunjukkan bahwa semakin bertambah usia ibu maka semakin baik kualitas dan akademik anak. Selaras dengan Hastuti (2009) bahwa kematangan usia ibu dapat membentuk kestabilan emosi dan kemampuan pengendalian emosi diri. Selain itu, kematangan berpikir dapat membentuk kematangan sosial emosi seseorang sehingga membentuk perilaku ketika berinteraksi dengan anak.

Tabel 5 Hasil uji hubungan antara karakteristik keluarga, karakteristik anak, dan karakteristik lingkungan petani dengan kualitas anak

\begin{tabular}{|c|c|c|c|c|c|}
\hline Variabel & Fisik & Akademik & Psikososial & Perilaku Anak & Kualitas Anak \\
\hline Usia anak & 0,098 & $0,365^{*}$ & $-0,293$ & 0,014 & 0,303 \\
\hline $\begin{array}{l}\text { Tingkatan kelas } \\
\text { anak }\end{array}$ & 0,135 & 0,094 & $-0,234$ & 0,187 & 0,119 \\
\hline $\begin{array}{l}\text { Jumlah anak yang } \\
\text { masih sekolah }\end{array}$ & 0,063 & $-0,015$ & 0,228 & $-0,013$ & 0,048 \\
\hline Besar keluarga & 0,183 & $-0,271$ & $0,492^{* *}$ & 0,021 & $-0,105$ \\
\hline Usia ayah & 0,032 & 0,309 & 0,040 & $-0,118$ & 0,274 \\
\hline Usia ibu & 0,020 & $0,379^{*}$ & $-0,088$ & 0,097 & $0,380^{*}$ \\
\hline Pendidikan ayah & $-0,143$ & 0,132 & 0,320 & $-0,223$ & 0,105 \\
\hline Pendidikan ibu & $-0,142$ & 0,020 & 0,231 & $-0,261$ & $-0,037$ \\
\hline $\begin{array}{l}\text { Pendapatan } \\
\text { keluarga per kapita }\end{array}$ & $-0,497^{* *}$ & 0,113 & $-0,402^{*}$ & $-0,008$ & $-0,077$ \\
\hline $\begin{array}{l}\text { Akses sarana } \\
\text { pendidikan }\end{array}$ & 0,058 & 0,299 & $-0,245$ & $-0,012$ & 0,236 \\
\hline $\begin{array}{l}\text { Akses sarana } \\
\text { kesehatan }\end{array}$ & $-0,309$ & $-0,056$ & $-0,039$ & $-0,249$ & $-0,198$ \\
\hline
\end{tabular}



Hasil uji korelasi Pearson menunjukkan bahwa terdapat hubungan negatif sangat signifikan $(r=-0,497, \quad p<0,01)$ antara pendapatan keluarga per kapita dengan dimensi fisik anak (Tabel 5). Artinya, semakin tinggi pendapatan keluarga per kapita maka semakin rendah fisik anak. Hasil ini didukung dengan wawancara mendalam bahwa keluarga petani responden yang memiliki pendapatan tinggi pun cenderung mengalokasikan pendapatannya untuk memenuhi kebutuhan pangan keluarga dan modal usaha tani. Selain itu, terdapat hubungan negatif signifikan $(r=-0,402, p<0,05)$ antara pendapatan keluarga per kapita dengan dimensi psikososial anak. Hal ini menunjukkan bahwa semakin tinggi pendapatan keluarga per kapita maka semakin rendah psikososial anak. Menurut Maholmes dan King (2012), anak yang berasal dari keluarga ekonomi menengah ke bawah memiliki masalah psikososial lebih buruk seperti masalah perilaku, masalah emosional, gangguan jiwa, dan kelainan fungsi sosial dibandingkan anak yang berasal dari keluarga ekonomi menengah ke atas (Tabel 5).

\section{Hubungan antara Investasi dan Kualitas Anak}

Pola asuh berhubungan signifikan negatif $(r=-0,381, p<0,05)$ dengan dimensi perilaku anak (Tabel 6). Artinya, semakin baik pola asuh yang dilakukan orang tua maka semakin rendah perilaku anak. Hasil ini tidak sesuai dengan Bronfenbrenner (1979) bahwa salah satu lingkungan yang terdekat dengan kehidupan anak dalam model ekologi keluarga adalah lingkungan mikro yang membantu anak untuk mengeksplorasi tumbuh kembangnya. Interaksi yang terjadi dalam lingkungan mikro membantu proses pengasuhan anak yang akan berdampak pada perkembangan anak. Hal ini terjadi karena pola asuh yang diterapkan tidak didukung dengan nilai-nilai norma (budaya, sosial, ekonomi, dan pendidikan) dan pengawasan dari orang tua, sehingga perkembangan perilaku anak kurang baik. Hubungan positif signifikan $(r=0,382, p<0,05)$ juga ditemukan antara alokasi waktu ibu dengan dimensi perilaku anak (Tabel 6). Artinya, semakin tinggi alokasi waktu ibu maka semakin tinggi perilaku anak. Dalam hasil penelitian menunjukkan bahwa waktu yang dihabiskan ibu pada kegiatan bersama dengan anak adalah 16-30 menit dan 46-60 menit. Sejalan dengan penelitian Caceres (2004), ratarata jumlah waktu ibu untuk menghabiskan waktu dengan anaknya dapat kemungkinan berdampak positif terhadap perkembangan anak. Hasil uji hubungan investasi anak dengan kualitas anak dapat dilihat pada Tabel 6 .
Tabel 6 Hasil uji hubungan investasi anak dengan kualitas anak

\begin{tabular}{|c|c|c|c|c|}
\hline \multirow{2}{*}{$\begin{array}{l}\text { Indeks } \\
\text { Investasi } \\
\text { Anak } \\
\end{array}$} & \multicolumn{4}{|c|}{ Indeks Kualitas Anak } \\
\hline & FK & $\mathrm{KF}$ & PS & PA \\
\hline $\begin{array}{l}\text { Alokasi } \\
\text { pengeluaran } \\
\text { Keluarga }\end{array}$ & $-0,132$ & $0, \overline{132}$ & 0,116 & 0,016 \\
\hline $\begin{array}{l}\text { Alokasi } \\
\text { pengeluaran } \\
\text { khusus } \\
\text { anak }\end{array}$ & $-0,208$ & 0,066 & $-0,046$ & 0,077 \\
\hline $\begin{array}{l}\text { Fasilitas } \\
\text { investasi }\end{array}$ & - & $0, \overline{122}$ & 0,102 & $-0,143$ \\
\hline $\begin{array}{l}\text { Frekuensi } \\
\text { komunikasi }\end{array}$ & - & $\overline{-}, 064$ & 0,153 & $-0,116$ \\
\hline Pola asuh & $-0,217$ & 0,128 & $-0,165$ & - \\
\hline $\begin{array}{l}\text { Alokasi } \\
\text { waktu ibu }\end{array}$ & 0,007 & 0,111 & $-0,034$ & $0,382^{*}$ \\
\hline $\begin{array}{l}\text { Alokasi } \\
\text { waktu anak }\end{array}$ & 0,154 & 0,274 & $-0,144$ & 0,142 \\
\hline
\end{tabular}

\section{PEMBAHASAN}

Merencanakan investasi anak dalam keluarga merupakan tindakan penting untuk mendapatkan hasil sumber daya manusia yang berkualitas di masa yang akan datang. Orang tua dapat melakukan investasi anak dengan cara memberikan kebutuhan pendidikan, pemeliharaan kesehatan, dan memberikan kasih sayang melalui pengasuhan yang layak untuk anak. Menurut Becker (1991), diacu dalam Routledge (2004), orang tua melakukan investasi bertujuan untuk memaksimalkan penghasilan bagi anaknya.

Investasi anak dalam penelitian ini terdiri atas investasi materi dan nonmateri. Hasil penelitian menunjukkan bahwa investasi anak pada keluarga petani responden tergolong kategori sedang dengan rata-rata nilai investasi per anak sebesar 61,0 persen. Artinya, keluarga petani responden dapat memberikan investasi secara materi dan nonmateri kepada anaknya relatif cukup baik. Walaupun latar pendidikan orang tua dalam penelitian ini hanya menempuh pendidikan sampai dengan $\mathrm{SD} /$ sederajat dan memiliki pendapatan yang kurang akan tetapi orang tua masih dapat melakukan investasi untuk anak. Hasil ini didukung dengan Caceres (2004) dalam penelitiannya bahwa latar belakang orang tua menentukan keberhasilan pendidikan dan ekonomi seorang anak di masa depan. 

Keberhasilan orang tua melakukan investasi akan berdampak pada hasil kualitas anak yang baik. Sunarti (2004) menyatakan bahwa kualitas anak merupakan cerminan kualitas bangsa dan peradaban dunia. Salah satu indikator kesejahteraan masyarakat dilihat dari kualitas hidup anak. Kualitas anak atau derajat kehandalan anak dapat diwakili dari dimensi pertumbuhan dan perkembangan anak seperti fisik, kognitif, psikososial, dan perilakunya. Hasil penelitian menunjukkan bahwa kualitas anak dari keluarga responden tergolong kategori sedang karena investasi anak yang dilakukannya pun relatif sedang. Hal ini didukung dari hasil penelitian ini bahwa keluarga petani responden hanya mengeluarkan kebutuhan nonpangan untuk anak sebesar 19,9 persen. Sejalan dengan Soetjiningsih (1995) bahwa keluarga yang berpenghasilan rendah seperti keluarga petani untuk meningkatkan kualitas anak masih belum merupakan prioritas utama dalam keluarga tersebut. Kualitas anak atau dikenal dengan capaian perkembangan anak sangat penting diperhatikan oleh orang tua. Tahap-tahap perkembangan anak sangat penting diperhatikan oleh orang tua. Gagalnya salah satu tahap perkembangan anak maka berdampak pada perkembangan anak selanjutnya.

Investasi anak berhubungan dengan kualitas anak. Hasil ini sejalan dengan penelitian Afriana (2012) menunjukkan adanya hubungan yang positif antara investasi anak dengan kualitas anak. Artinya, dengan melakukan investasi terhadap anak maka akan meningkatkan kualitas anak yang dapat dilihat dari perkembangan fisik, akademik, psikososial, dan perilaku. Dalam penelitian ini terdapat hubungan negatif dan signifikan antara pola asuh dengan dimensi perilaku anak. Afriana (2012) dalam penelitiannya menunjukkan bahwa semakin tinggi pola asuh yang dilakukan oleh orang tu maka semakin rendah perkembangan perilaku anak.

Selain itu, terdapat hubungan positif dan signifikan antara alokasi waktu ibu dengan dimensi perilaku anak. Hal ini menunjukkan bahwa semakin tinggi alokasi waktu ibu maka semakin tinggi perkembangan perilaku anak. Hasil ini selaras dengan Sunarti (2004), pengasuhan yang berkaitan dengan pola asuh sangat menentukan kompetensi anak dengan melibatkan perilaku secara sosial agar dapat diterima sebagai perilaku bertanggung jawab, perilaku mandiri, mampu bekerja sama, bersahabat, dan orientasi pada prestasi.

\section{SIMPULAN DAN SARAN}

Investasi anak meningkat dengan semakin bertambahnya usia anak. Investasi anak juga akan meningkat dengan bertambahnya lama ayah dan ibu dalam mengikuti pendidikan formal. Investasi anak berbentuk materi dan nonmateri. Investasi anak dalam bentuk nonmateri yaitu pola asuh justru menurunkan kualitas. Hal ini dikarenakan pola asuh yang diterapkan tidak disertai dengan nilai-nilai norma (budaya, sosial, ekonomi, dan pendidikan) dan pengawasan dari orang tua sehingga perkembangan perilaku anak kurang baik. Kualitas anak juga berhubungan dengan alokasi waktu ibu. Kualitas anak meningkat dengan semakin besar waktu yang dapat dialokasikan ibu untuk anak.

Investasi yang dilakukan oleh keluarga petani untuk anak masih rendah. Rata-rata pendapatan yang diperoleh keluarga petani lebih banyak dialokasikan pada kebutuhan pangan dibandingkan nonpangan. Oleh karena itu, perlu adanya peningkatan kesadaran dan pengetahuan melalui sosialisasi manajemen keuangan keluarga yang lebih baik terutama mengalokasikan kebutuhan investasi anak. Adapun bentuk sosialisasi ini mencakup manajemen pendapatan dan pengeluaran keluarga. Hal ini perlu dilakukan karena masih banyak keluarga yang memprioritaskan daya beli untuk kebutuhan pangan dibandingkan kebutuhan nonpangan anak.

\section{DAFTAR PUSTAKA}

Afriana, H. (2012). Analisis investasi dan kualitas anak pada keluarga nelayan di Kabupaten Sukabumi (skripsi). Institut Pertanian Bogor, Bogor.

[BKKBN] Badan Koordinasi Keluarga Berencana Nasional. (1998). Opini pembangunan keluarga sejahtera. Diambil dari http://bkkbn.go.id. [diunduh 22 Feb 2012].

Bronfrenbenner, U. (1979). The ecology of human development: Experiments by nature and design. United States of America (US): President and Fellows of Harvard Collage.

[BPS] Badan Pusat Statistik. (2011). Kabupaten Cirebon dalam angka Tahun 2011. Diambil dari http://www.cirebonkab. bps.go.id. [diunduh 22 Feb 2012].

Caceres, J. (2004). Impact of family size on investment in child quality: Multiple births as a natural experimental. E-journal of 

Applied Microeconomics, 1-42. Diambil dari http://www.tinbergen.nl/cost/london/ caceres.pdf. [diunduh 22 Feb 2012].

Gunarsa, S. D., \& Gunarsa, Y. S. D. (1995). Psikologi perkembangan anak dan remaja. Yogyakarta, ID: BPK Gunung Mulia.

Hastuti, D., Fiernanti, D. Y. I., \& Guhardja, S. (2011). Kualitas lingkungan pengasuhan dan perkembangan sosial emosi anak usia balita di daerah rawan pangan. Jurnal IImu Keluarga \& Konsumen, 4(1), 57-56.

Hastuti, D. (2009). Pengasuhan: Teori dan prinsip serta aplikasinya di indonesia. Bogor: Departemen IImu Keluarga dan Konsumen, Institut Pertanian Bogor.

Hurlock, E. B. (1980). Psikologi perkembangan. Edisi ke-5. Jakarta, ID: Erlangga.

Lee, J. (2007). Sibling size and investment in children's education: An asian instrument. Journal of Population Economics, 21(4), 855-875. doi:10.1007/s00148-006-0124-5.

Lino, M. (2004). Expenditure on children by families, 2003. Journal of Family Economics and Nutrition Review, 16(1), 31-38.

Malhomes, V., \& King, R. (2012). The books oxford handbook of poverty and child development. Malhomes, V. \& King, R., (Eds.). England, UK: Oxford University Press, Inc.

Puspitawati, H. (2010). Pengaruh karakteristik sosial ekonomi keluarga terhadap pola asuh belajar siswa sekolah dasar dan menengah pertama. Jurnal IImu Keluarga dan Konsumen, 3(1), 46-55.
Rochaeni, S., \& Lokollo, E. M. (2005). Faktorfaktor yang mempengaruhi keputusan ekonomi rumah tangga petani di kelurahan setugede kota bogor. Jurnal Agro Ekonomi, 23(2), 133-158.

Rosidah, U., Hartoyo, \& Muflikhati, I. (2012). Kajian strategi koping dan perilaku investasi anak pada keluarga buruh pemetik melati gambir. Jurnal IImu Keluarga dan Konsumen, 5(1), 77-87.

Routledge. (2004). Family investment in children's potensial: Resources and parenting behaviors that promote success. New Jersey, US: Lawrence Erlbaum Associates, Inc. Mahwah.

Santrock, J. W. (2007). Perkembangan anak Ed.11. Racmawati, Kuswanti, penerjemah; Hardani, W (Eds.). Jakarta, ID: PT Gelora Aksara Pratama. Terjemahan dari: Child Development.

Soetjiningsih. (1995). Tumbuh kembang anak. Ranuh, G., editor. Jakarta, ID: Buku Kedokteran EGC.

Sunarti, E. (2004). Mengasuh dengan hati: Tantangan yang menyenangkan. Jakarta, ID: PT Elex Media Komputindo.

Tangdilintin, P. (2008). Pembinaan Generasi Muda. Yogjakarta, ID: PT. Kanisius.

Todaro, M.P., \& Smith, S.C. (2006). Pembangunan ekonomi Jilid 1. Edisi ke-9. Munandar, P., penerjemah; Baranadi, D., Saat, S., \& Hardani, W., (Ed.). Jakarta, ID: PT Gelora Aksara Pratama. Terjemahan dari: Economic Development. 